\title{
ZBTB33 Gene
}

National Cancer Institute

\section{Source}

National Cancer Institute. ZBTB33 Gene. NCI Thesaurus. Code C155729.

This gene plays a role in the regulation of both gene transcription and signal transduction. 